\title{
Conjugation of \\ daunorubicin to monoclonal antihuman sarcoma \\ antibody by a novel method
}

Michel Pagé, Denis Thibeault, Hélène Tremblay, Christiane NoËl, Marie-Josée Perron

\begin{abstract}
M Pagé, D Thibeault, h Tremblay, C Noël, MJ Perron. Conjugation of daunorubicin to monoclonal antihuman sarcoma antibody by a novel method. Can $J$ Infect Dis 1992;3(Suppl B): 101B-105B. Most of the reported methods for coupling anthracycline drugs to antibody result in either a loss of pharmacological activity or yield antibodies which have lost much of their immunological specificity. The use of glutaraldehyde for coupling saves both the pharmacological and immunological activities but it causes some polymerization of the antibody or of the macromolecular carrier which is undesirable for in vivo use. A new coupling procedure is reported which uses an activated derivative of daunorubicin added to monoclonal antihuman sarcoma antibody. This coupling procedure has not resulted in significant polymerization of the antibody or loss of pharmacological activity determined by testing normal and tumour cell lines in vitro.
\end{abstract}

Key Words: Carrier, Conjugation, Daunorubicin, Glutaraldehyde, Immunotherapy, Monocolonal, Osteosarcoma

\section{Nouveau mode d'association de la daunorubicine et de l'anticorps monoclonal antisarcome}

RÉSUMÉ: La plupart des méthodes rapportées quant à l'association de médicaments à base d'anthracyclines et d'anticorps donnent lieu soit à une perte d'activité pharmacologique ou à des anticorps dépourvus d'une bonne part de leur spécificité immunologique. L'utilisation de glutaraldéhyde pour l'association protège tant l'activité pharmacologique qu'immunologique, mais provoque également un certain degré de polymérisation de l'anticorps du porteur macromoléculaire, ce qui est à éviter pour un usage in vivo. Un nouveau mode d'association est présenté ici; il suppose le recours à un dérivé activé de la daunorubicine ajouté à l'anticorps monoclonal antisarcome. Cette nouvelle technique d'association n'a pas donné lieu à une polymérisation significative de l'anticorps, ni à une perte au plan de l'activité pharmacologique, comme l'attestent les épreuves in vitro portant sur des lignées cellulaires normales et tumorales. 
$\mathrm{T}$ HE USE OF CYTOTOXIC DRUGS FOR THE TREATMENT OF cancer can be accompanied by side effects due in part to the nonspecificity of these agents. Such drugs can cause various toxicities including nausea, vomiting, immunosuppression, alopecia and cardiotoxicity. In order to reduce secondary effects and increase tumour cell kill without exceeding dose limiting toxicity, the drugs were coupled to carriers such as antibodies which recognize tumour cells. Desirable carrier antibodies are those which react with cancerassociated antigens expressed on the surface of tumour cells and not found in significant quantity exposed on the surface of normal cells in vital organs $(1,2)$.

During the past 20 years, many groups have used this new approach for coupling agents such as chlorambucil $(3,4)$, methotrexate $(5,6)$, mitomycin $\mathrm{C}(7,8)$, toxins $(9,10)$ and anthracyclinediones $(11,12)$. Anthracyclinediones such as doxorubicin and daunorubicin (Figure 1) are widely used and have been coupled to various carriers in order to reduce systemic cytotoxicity and cardiotoxicity. Most of the reported conjugation procedures cause some loss of immunological activity.

Hurwitz et al $(11,13)$ reported the coupling of doxorubicin to a carrier by periodate oxidation. The drug was also indirectly coupled to the antibody by means of a dextran bridge $(11,14)$. This intermediary bridge was used to increase the drug:antibody ratio.

A few authors have reported that periodate oxidation could also affect the daunosamine $(15,16)$ and the cetonic function at C-14 which are essential for the pharmacological activity of the drug (17). Some immunological loss was also reported $(11,13,14)$ due to the presence of sodium borohydride which could cleave the disulphide bonds of the antibody (18-20).

Other methods have also been reported for daunorubicin conjugation such as EDCI (1-[3-dimethylaminopropyl]3-ethyl-carbodiimide hydrochloride) (11) for intermediary bridges such as cis-aconityl, maleyl and succinyl (21). Usually, an important loss of pharmacological activity was observed using these techniques.

The authors have already reported the use of glutaraldehyde as an agent for anthracycline coupling to protein carriers $(2,22,23)$. This method saves the pharmacological activity but causes some polymerization of the protein carriers. Based on the results obtained with glutaraldehyde and taking the advantages of the activated ester coupling procedure, a glutaraldehyde-activated derivative of daunorubicin was prepared for a direct coupling to a monoclonal antibody. This new approach for the preparation of daunorubicin protein carrier conjugates is reported.

\section{MATERIAL AND METHODS}

Preparation of glutaraldehyde-activated daunorubicin: Daunorubicin hydrochloride (1 mg) was dissolved in $4 \mathrm{~mL}$ of $0.05 \mathrm{M}$ phosphate buffer at $\mathrm{pH} 7.5$ and

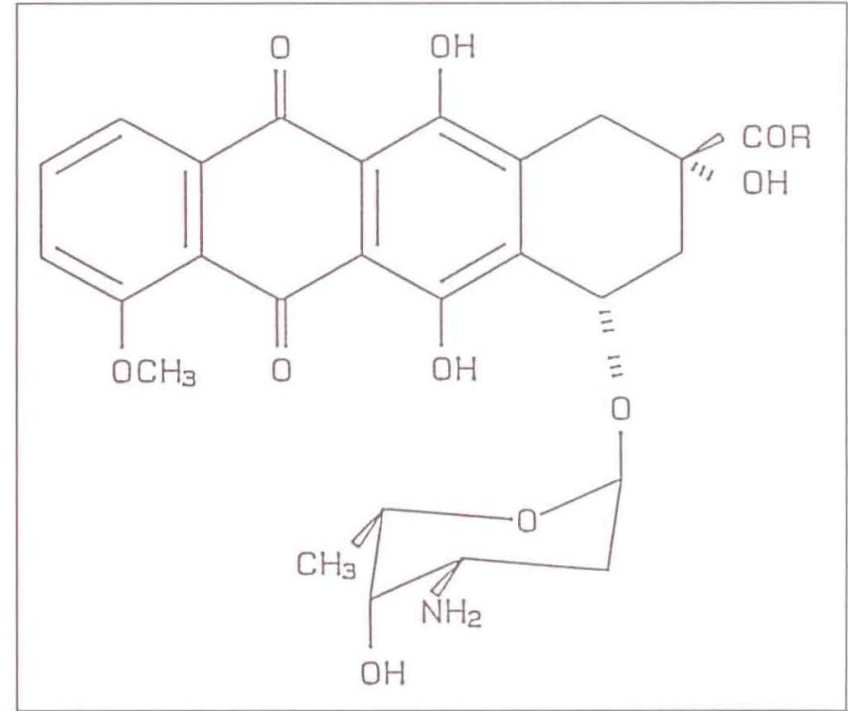

Figure 1) Structure of daunorubicin $\left(\mathrm{R}=\mathrm{CH}_{3}\right)$ and doxorubicin $\left(\mathrm{R}=\mathrm{CH}_{2} \mathrm{OH}\right)$

$60 \mu \mathrm{L}$ of $25 \%$ glutaraldehyde added (grade II, Sigma Chemicals, Missouri). The mixture was stirred for 15 mins at room temperature and $1 \mathrm{~mL}$ of distilled water added. The mixture was extracted twice with $5 \mathrm{~mL}$ of dichloromethane; the organic phases were pooled and treated four times with an equal volume of $5 \%$ sodium bicarbonate solution containing 15\% glycine. The organic phase was dried with anhydrous sodium sulphate, filtered and the solvent evaporated under a stream of nitrogen at $30^{\circ} \mathrm{C}$. The dried product was solubilized in a minimum volume of dimethylsulphoxide (DMSO). The activated product had an $R_{f}$ of 0.80 in the solvent described compared with 0.25 for free daunorubicin. The coefficient of extinction $\mathrm{E}^{1 \%}$ was 176 in $10 \%$ DMSO in 0.05 M phosphate buffer at $\mathrm{pH} 7.2$.

Monoclonal antibody: Embryonic prealbumin is a protein of mesodermal origin first reported by Kalashnikov and Tatarinov $(24,25)$ in desmoid tumours and soft tissue cancers. Embryonic prealbumin was prepared according to Drouin (26) and $250 \mu \mathrm{g}$ were inoculated intradermally into Balb-C mice with complete Freund's adjuvant. Animals received a second and third booster at one month intervals. Four days after the third inoculation the animals were sacrificed and splenocytes collected for fusion with NS-1 myeloma cells. Hybridoma-containing wells were cloned and each of the monoclonal antibodies was tested for reactivity with embryonic prealbumin supplied by Kalashnikov and Tatarinov. Monoclonal 4E8 or G10 used in this experiment were specific for embryonic prealbumin; both are of the $\operatorname{IgG}_{1} \mathrm{~K}$ isotype.

Cells: All human cell lines were obtained frozen from the American Type Culture Collection (Maryland) where they were routinely propagated in RPMI 1640 medium supplemented with $10 \%$ fetal bovine serum. CRL- 1427 and SaOs-2 are from an osteosarcoma and CCL-25 from amnion. 


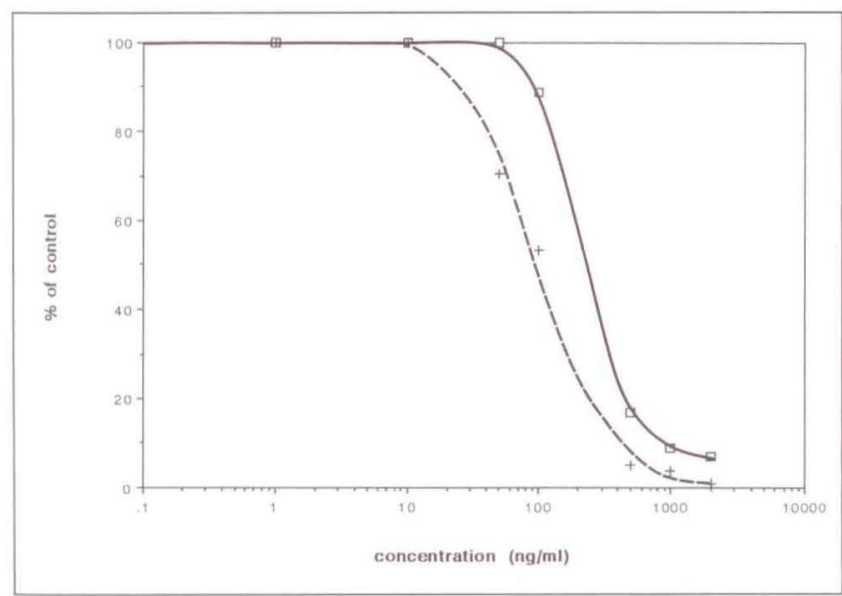

Figure 2) Cytotoxicity of equimolar concentrations of free (미 or monoclonal anti-EPA bound (+) daunorubicin on human osteosarcoma cells (CRL-1427)

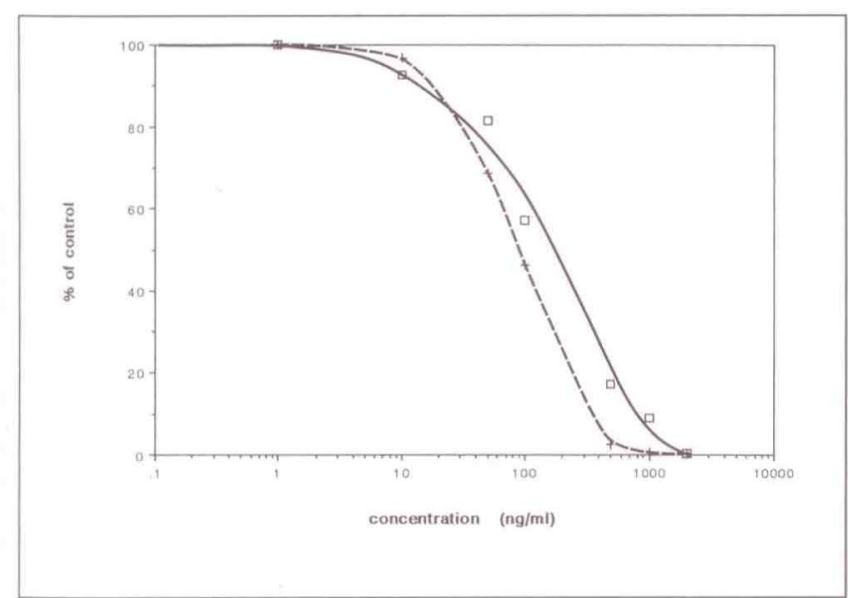

Figure 3) Cytotoxicity of equimolar concentrations of free (ㅁ) or monoclonal anti-EPA bound ( + ) daunorubicin on human osteosarcoma cells (SaOs-2)

\section{CONJUGATION PROCEDURE TO ANTIBODIES}

Antibody purification: Monoclonal antiembryonic prealbumin (anti-EPA) was purified from mouse ascitic fluid by precipitation with $50 \%$ saturated ammonium sulphate. The antibody precipitate was dissolved in the original volume of phosphate buffer at $\mathrm{pH} 7.2$ and dialyzed for $24 \mathrm{~h}$ at $4^{\circ} \mathrm{C}$ against phosphate buffer. The antibody concentration was measured using the Lowry method (27). Monoclonal antibodies against carcinoembryonic antigen (anti-CEA) and alpha-fetoprotein prepared in the authors' laboratory were purified by the same procedure. The glutaraldehyde-activated daunorubicin derivative was dissolved in $100 \mu \mathrm{L}$ of DMSO and added with stirring to $500 \mu \mathrm{g}$ of monoclonal antibody dissolved in $400 \mu \mathrm{L}$ of phosphate buffer. The reaction mixture was incubated for 60 mins at $37^{\circ} \mathrm{C}$ and the protein conjugate was separated on Sephadex G-25 on a PD-10 column (Pharmacia) equilibrated with $0.05 \mathrm{M}$ ammonium acetate at $\mathrm{pH} 6.5$ containing $0.3 \mathrm{mM}$ glycine. The conjugate appeared in the void volume of the column. The conjugation ratio was determined by spec-

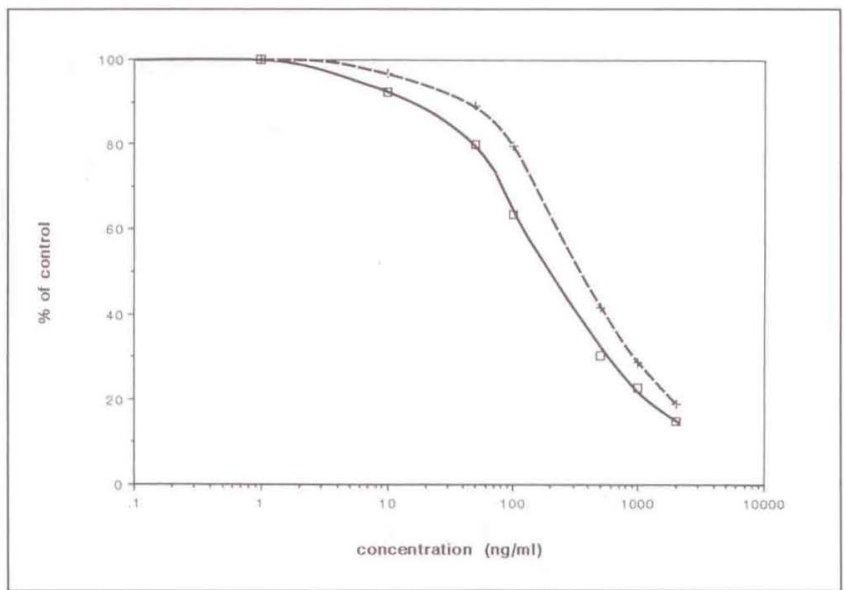

Figure 4) Cytotoxicity of equimolar concentrations of free (ㅁ) or monoclonal anti-EPA bound ( + ) daunorubicin on human amnion cells (CCL-25)

trophotometry assuming an $\mathrm{E}^{1 \%}$ of 176 for daunorubicin and 14.5 for monoclonal antibodies.

In vitro cytotoxicity: Due to the nonspecific adsorption of daunorubicin on filtration membranes, the conjugates were sterilized by irradiation before in vitro testing as follows. The conjugate solution was adjusted to $20 \mathrm{mg}$ albumin $/ \mathrm{mL}$ in $0.05 \mathrm{M}$ ammonium acetate buffer. The solution was freeze dried and gamma radiated with 160 Gy. Before the assay, the dry conjugate was taken up in phosphate buffer and added at various concentrations to culture medium.

The cytotoxic activity of daunorubicin and antibody conjugates was evaluated on various cell lines by inhibition of colony formation as already described (28). Briefly, 2500 cells were inoculated into $1 \mathrm{~mL}$ of RPMI 1640 medium supplemented with 10\% fetal bovine serum in 24-well plates. Cells were allowed to attach for $24 \mathrm{~h}$, medium was removed and replaced by various test compounds diluted in growth medium. Each assay was performed in quadruplicate. After the growth period, medium was decanted, and colonies were fixed with formol and stained with crystal violet as previously reported by Belles-Isles and Pagé (1). The area occupied by the colonies was measured with Biotran III (New Brunswick Scientific, New Jersey) (28).

In order to study the internalization of the conjugate, 2500 cells per well were seeded on a microtitration plate and incubated for two days in the medium described above. After this period, $250 \mathrm{ng} / \mathrm{mL}$ of free or conjugated daunorubicin were added and cells were incubated for four days at $37^{\circ} \mathrm{C}$; cells were counted with the tetrazolium-based colorimetric assay (29).

\section{RESULTS}

Glutaraldehyde-activated daunorubicin: When the new method was used for coupling daunorubicin to the antibody, molar ratios of drug:antibody were obtained, varying from 0.5 to 13 . The original method $(1,22,23)$ yielded conjugates with comparable drug:protein ratios 
TABLE 1

$\mathrm{IC}_{50}$ of free and bound daunorubicin for various cell lines

\begin{tabular}{lccc}
\hline Cell line & $\begin{array}{c}\text { Free drug } \\
(\mathrm{ng} / \mathrm{mL})\end{array}$ & $\begin{array}{c}\text { Conjugate } \\
(\mathbf{n g} / \mathrm{mL})\end{array}$ & IC $_{50}$ ratio* \\
\hline CRL-1427 & 230 & 90 & 2.55 \\
$\begin{array}{l}\text { SaOs-2 (osteo- } \\
\text { sarcoma) }\end{array}$ & 150 & 90 & 1.68 \\
CCL-25 (amnion) & 170 & 380 & 0.44 \\
\hline
\end{tabular}

" $C_{50}$ free drug// $C_{50}$ conjugate

but with considerable polymerization of the antibody. The overall coupling yield using the present method was larger than $75 \%$. When the ratio of glutaraldehyde to daunorubicin was varied, the optimal ratio of reagents was $1 \mathrm{mg}$ daunorubicin $(2 \mu \mathrm{mol})$ for $60 \mu \mathrm{L}$ of a $25 \%$ aqueous solution of glutaraldehyde $(100 \mu \mathrm{mol})$. In preliminary experiments, there were some variations in the yields of coupled daunorubicin. Various factors could affect the reactive aldehyde present on activated daunorubicin; these could be eliminated by thoroughly rinsing the reaction vessels before the reaction with double distilled water.

Cytotoxicity of conjugates: Results obtained by inhibition of colony formation on the cytotoxicity of free or anti-EPA-bound daunorubicin are shown in Figures 2 to 4 . For any cell line used, there was a dose-response relationship. The cytotoxicity of anti-EPA conjugate for CRL-1427 cells was $90 \mu \mathrm{g} / \mathrm{mL}$ compared with 230 $\mathrm{ng} / \mathrm{mL}$ for free drug; the cytotoxicity of anti-EPA conjugate for human osteosarcoma SaOs-2 cells was also $90 \mathrm{ng} / \mathrm{mL}$ for the conjugate versus $150 \mathrm{ng} / \mathrm{mL}$ for free drug. The conjugate was less cytotoxic for EPA-negative cells (normal human amnion CCL-25 cells) thus showing some specificity for osteosarcoma cells. The IC50 of free and bound daunorubicin for the various cell lines is reported in Table 1.

\section{DISCUSSION}

These results confirm the already reported activity of the conjugates prepared with glutaraldehyde in the authors' laboratory. However, using long term incubations, specificity of the conjugate for the tumour cells is not expected as the anthracycline is released very slowly from the antibody at physiological $\mathrm{pH}$. When cells were incubated with $250 \mathrm{ng} / \mathrm{mL}$ of free or conjugated daunorubicin for various periods, the growth inhibition by both conjugated and free drug increased with time (Figure 5); however, the full activity of the conjugate was obtained after four days of incubation. This was probably due to a slow internalization of the conjugateantigen complex. Other data also suggest that this is the limiting step, while the hydrolysis of the drug-antibody bond inside the cell is a very rapid reaction.

Results obtained with activated daunorubicin using this new procedure show that the pharmacological activity of the drug could be saved while limiting the

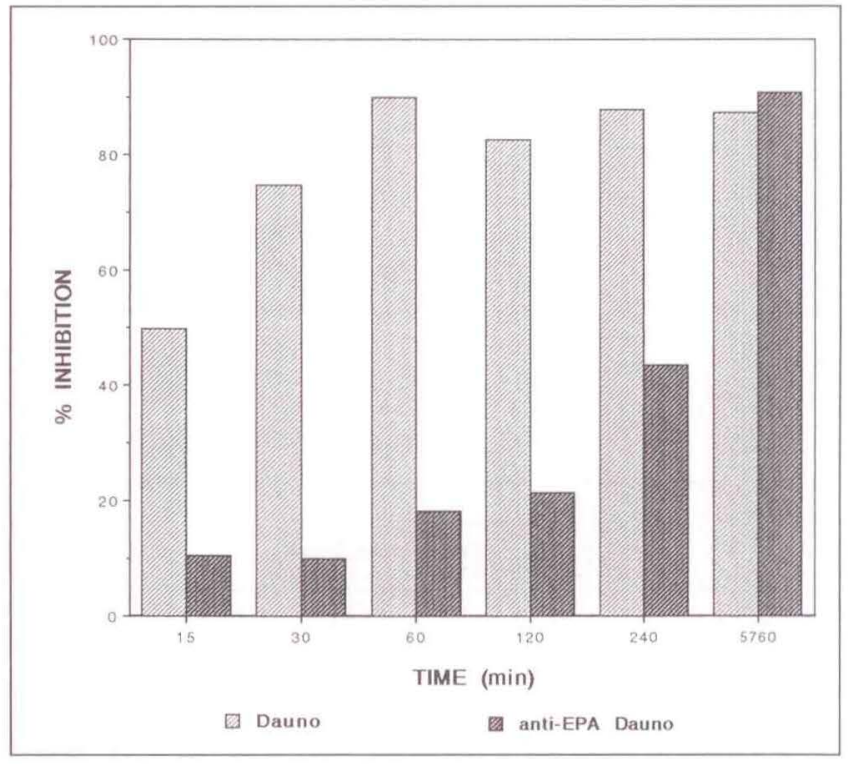

Figure 5) Cytotoxicity of free or conjugated daunorubicin after various periods with human osteosarcoma cells (CRL-1427)

undesirable polymerization of the antibody normally encountered with bivalent coupling agents. This procedure is easy and reproducible and reagents are readily available commercially. The activation of the drug could be accomplished in less than $2 \mathrm{~h}$ and the activated drug remains active for a week at room temperature. The activated drug could remain active for many months if saved in liquid nitrogen. The already reported techniques for coupling anthracycline drugs to antibody either cause polymerization or yield a product which is considerably less active than the free drug. The authors are using this new technique to conjugate a variety of monoclonal antibodies for drug targeting to various types of tumors.

ACKNOWLEDGEMENTS: This work was supported by the Cancer Research Society, Montreal, Quebec, and in part by the Medical Research Council of Canada and Rhône-Poulenc Rorer, Montreal, Quebec.

\section{REFERENCES}

1. Belles-Isles M, Page M. In vitro activity of daunomycine-anti-alpha-fetoprotein conjugate on mouse hepatome cells. Br J Cancer 1980;41:840.

2. Pagé M, Emond JP. Daunomycine targeting using carrier antibodies. In: G Mathé, eds. Anthracyclines. Paris: Masson, 1983:105-8.

3. Ghose T, Path C, Nigam SP. Antibody as carrier of chlorambucil. Cancer 1972;29:1398-1400.

4. Smyth MJ, Pietersz GA, Classon BJ, McKenzie IFC. Specific targeting of chloambucil to tumors with the use of monoclonal antibodies. J Natl Cancer Inst 1986;76:503-10.

5. Kanellos J, Pietersz GA, McKenzie IFC. Studies of methotrexate-monoclonal antibody conjugates for immunotherapy. J Natl Cancer Inst 1985;75:319-32.

6. Endo N, Kato Y, Takeda Y, Sato M, Umemoto N, Kishida $\mathrm{K}$. In vitro cytotoxicity of a human serum 
albumin-mediated conjugate of methotrexate with anti-MM46 monoclonal antibody. Cancer Res 1987;47:1076-80.

7. Kato Y, Tsukada Y, Hara T, Hirai HJ. Enhanced antitumor activity of mitomycin $\mathrm{C}$ conjugated with anti-alpha-fetoprotein antibody by a novel method of conjugation. Applied Biochem 1983;5:313-9.

8. Ohkawa K, Tsukada Y, Hibi N, Umemoto N, Hara T. Selective in vitro and in vivo growth inhibition against human SAC tumor cell lines by purified antibody against human anti-alpha-fetoprotein conjugated with mytomycin $C$ via human serum albumin. Cancer Immunol Immunother 1986;23:81-6.

9. Pau B, Blythman HE, Carrière D, et al. Cancer therapy potential of conjugates between a toxin subunit and antibodies. Immunopharmacology 1980;2:A(254).

10. Vitetta ES, Krolick KA, Miyama-Inaba M, Cushley W, Uhr JW. Immunotoxins: A new approach for cancer therapy. Science 1983;219:644-50.

11. Hurwitz E, Levy R, Maron R, Wilcheck M, Arnon R, Sela $M$. The covalent binding of daunomycin and adriamycin with retention of both drug and antibody activities. Cancer Res 1975;35:1176-81.

12. Tsukada Y, Kato Y, Umemoto N, Takeda Y, Hara T, Hirai H. An anti-alpha-fetoprotein antibody-daunomycin conjugate with a novel poly-L-glutamic acid derivative as intermediate drug carrier. J Natl Cancer Inst 1984;73:721-9.

13. Hurwitz E, Schechter B, Arnon R, Sela M. Binding of anti-tumor immunoglobulins and their daunomycin conjugates to the tumor and its metastases. In vitro studies with Lewis lung carcinoma. Int $J$ Cancer 1979;24:461-70.

14. Hurwitz E, Maron R, Arnon R, Wilcheck M, Sela M. Daunomycin-immunoglobulin conjugates: Uptake and activity in vitro. Eur J Cancer 1978; 14:1213-20.

15. Varga JM. In: Wilder KJ, Green R, eds. Hormone Drug Conjugates. Methods in Enzymology, volume 112. New York: Academic Press Inc, 1985:259-69.

16. Calendi E, Di Marco A, Reggiani M. Physicochemical interactions between daunomycin and nucleic acids.
Biochim Biophys Acta 1965; 103:25-49.

17. Arcamone F. In: De Stevens G, ed. Doxorubicin: Anticancer Antibiotics, volume 17. New York: Academic Press, 1981:175-6.

18. Means GE, Feeny RE. Chemical Modification of Proteins. San Francisco: Holden-Day Inc 1971:150-3.

19. Kress LF, Laskowski MJ. The basic trypsin inhibitors of bovine pancreas; III: Reduction with borhydride of disulfide bond linding half cystine residues 14 and 38 . J Biol Chem 1967;242:4925-9.

20. Light A, Sinka NK. Difference in the chemical reactivity of teh disulfide bonds of trypsin and chymotrypsin. J Biol Chem 1967;242:1358-9.

21. Gallego J, Price MR, Baldwin RW. Preparation of four daunomycin-monocolonal antibody $791 \mathrm{~T} / 36$ conjugates with antitumor activity. Int $\mathrm{J}$ Cancer 1984;33:737-44.

22. Belles-Isles M, Pagé M. Drug targeting with monocolonal antibodies. Int J Immunopharm 1981;3:97-102.

23. Pagé M, Emond JP, Gauthier C, Dufour C, Innes L. In: Peeters H, ed. Proteins in Biological Fluids. Oxford: Pergamon Press, 1982;29:933-6.

24. Kalashnikov VV, Borisenko SA, Tatarinov YS. Immunochemical identification of a new embryonic antigen in ovarian tumor tissue. Bull Exp Biol Med 1976;81:900.

25. Tatarinov YS, Kalashnikov VV, Vasiliev MY, Voloshuk SG. Human embryonic prealbumin as a marker for tumors and fibroblasts. Lancet 1978;ii: 1122 .

26. Drouin R. Isolation of embryonic prealbumin and immunohistological studies of sarcomas with monoclonal antibodies. Université Laval, Québec: Thesis, 1984:1-115.

27. Lowry OH, Rosenbrough NJ, Fan AL, Randal RJ. Protein measurement with the folin phenol reagent. J Biol Chem 1951;193:265-9.

28. Emond J-P, Pagé M. Lapis K, Jeney A, Price MR, eds. Tumor Progression and Markers. Amsterdam: Kugler Publications, 1982:467-70.

29. Pagé M, Bejaoui N, Cinq-Mars B, Lemieux P. Optimization of the tetrazolium-based colorimetric assay for the measurement of cell number and cytotoxicity. Int J Immunopharm 1988;10:785-93. 


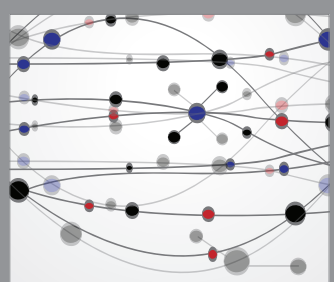

The Scientific World Journal
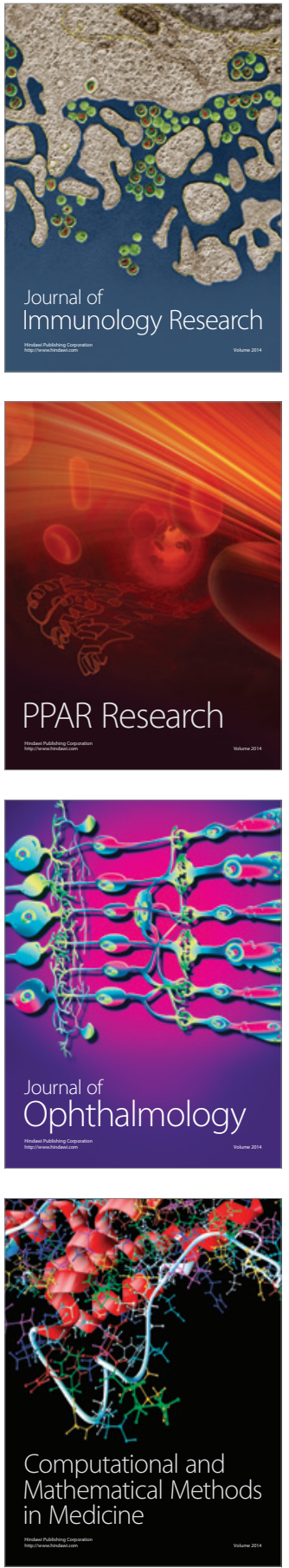

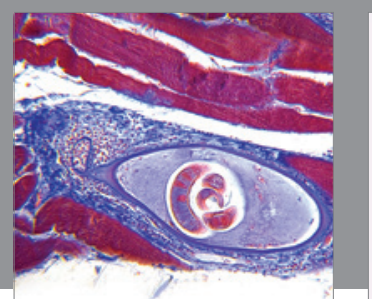

Gastroenterology Research and Practice

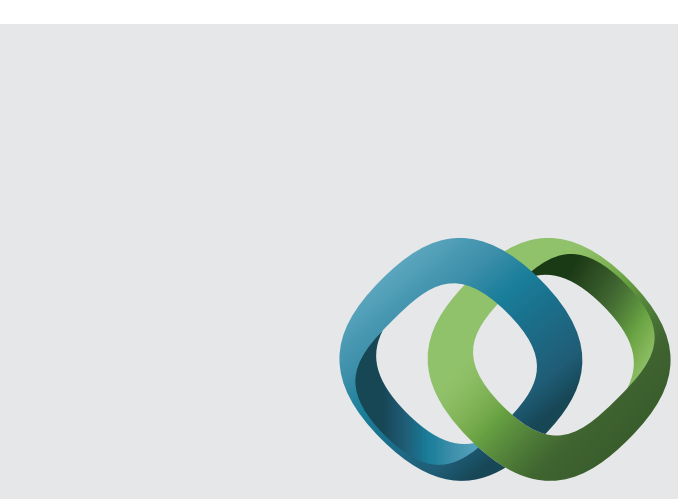

\section{Hindawi}

Submit your manuscripts at

http://www.hindawi.com
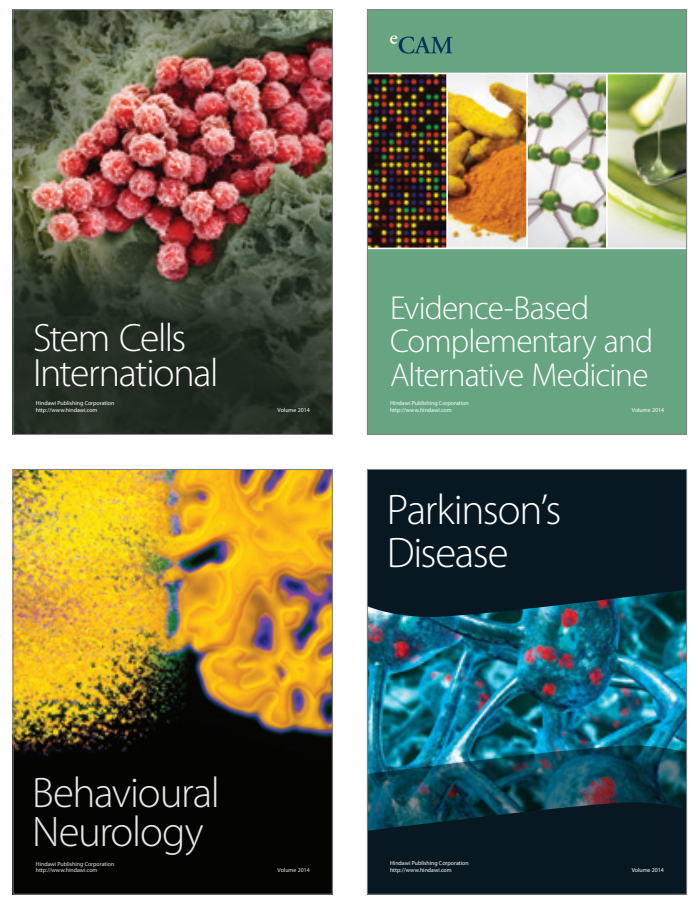
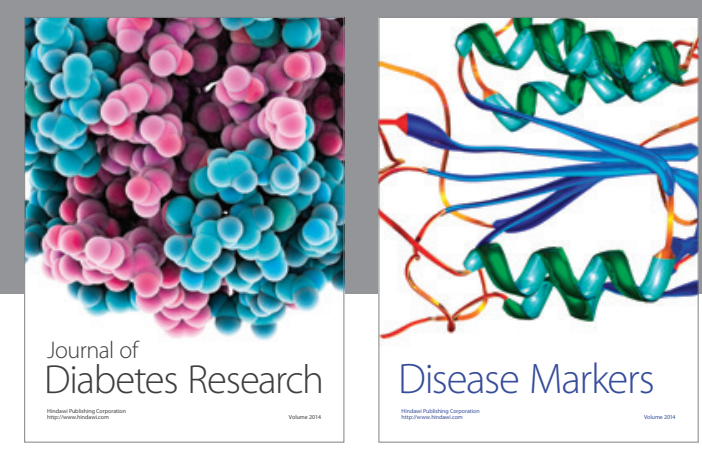

Disease Markers
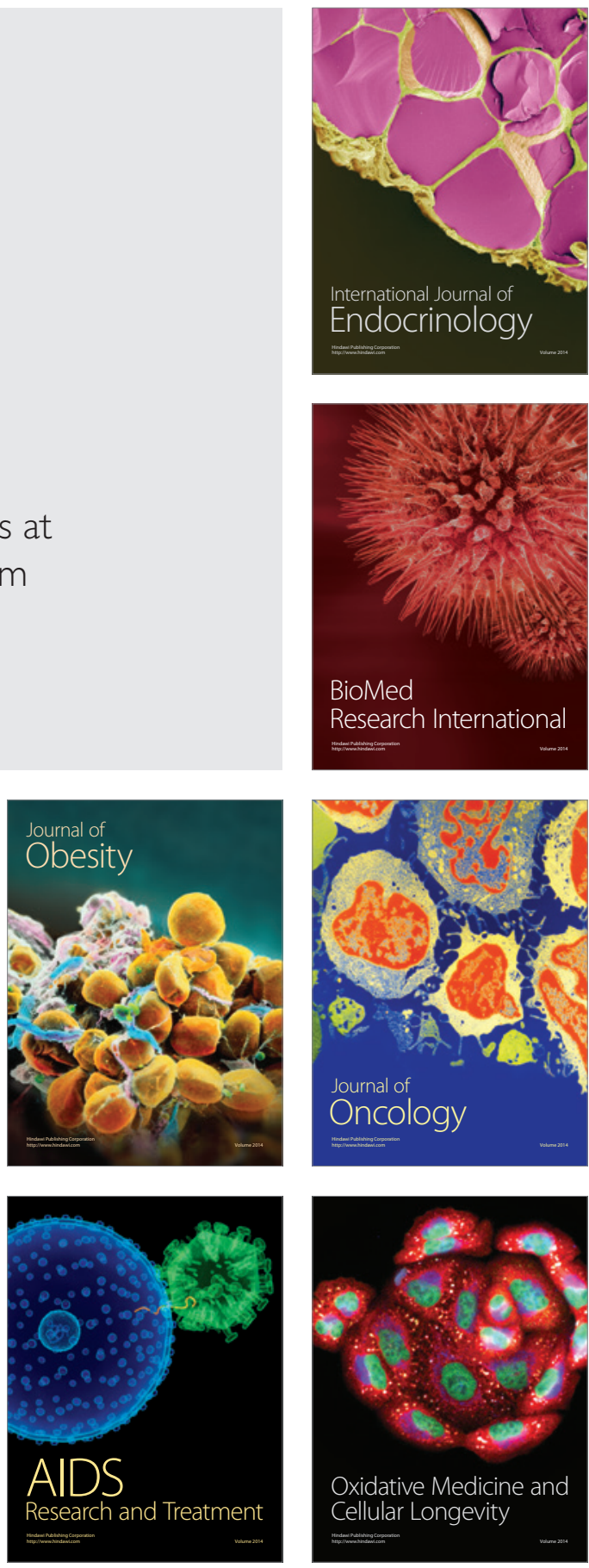